Amy Paris Langenberg

\title{
Love, Unknowing, and Female Filth: The Buddhist Discourse of Birth as a Vector of Social Change for Monastic Women in Premodern South Asia
}

Despite its ubiquity in the classical tradition, the premodern South Asian Buddhist tale of the suffering fetus in the filthy female womb is often read as medical, a pseudobiological interpolation in the "religious" canon of classical Buddhism. Leaving aside theoretical questions about how well categories like "science" and "religion" serve us in understanding premodern South Asian Buddhist cultural worlds, this essay argues that Buddhist narratives about the suffering fetus and the foul female womb have important and broad implications for the contestation of gender in South Asian Buddhist contexts. An oft-repeated trope, Buddhist descriptions of birth have been a powerful means - in language suggested by the editors of this volume - of "perennializing" a certain classical Buddhist ideology of the female reproductive body. They have also operated, as I argue here and elsewhere, as a "vector of social change" (again, using the language of the editors), albeit in ways both indirect and paradoxical. ${ }^{1}$ In the context of the profound suffering of birth (the central message of this ubiquitous trope), women's fertility and sexual desirability or readiness are not to be coveted and devoutly wished for. For this reason, men and women contemplating, reproducing, and circulating the Buddhist discourse of birth may have found it easier to conceive of women living another kind of life besides motherhood and wifehood.

Here, I argue that the Buddhist tale of the impure, disgusting, and violent female body and the suffering of the fetus within the womb, so seemingly negative toward women, in fact operated discursively and affectively to support premodern female Buddhist monasticism by helping to generate a moral-social imaginary in which female fertility and sexuality cannot be the highest good of womanhood. A discourse that denies the auspiciousness and sexual desirability of women as fundamental truths - as classical Buddhism does - would have posed a disruption to authoritative customs and norms regarding female nature and female virtue in premodern South Asia, customs and norms that many

1 Amy Paris Langenberg, Birth in Buddhism: The Suffering Fetus and Female Freedom (Abingdonon-Thames: Routledge Press, 2017).

๑ Open Access. @ 2021 Amy Paris Langenberg, published by De Gruyter. (c) BY-NC-ND This work is licensed under a Creative Commons Attribution-NonCommercial-NoDerivatives 4.0 International License. https://doi.org/10.1515/9783110674088-012 
Buddhists themselves would also have shared at some level. In particular, this essay explores nuns' vinaya texts related to menstruation and same-sex affection, in order to illuminate the radical social-moral space of female Buddhist asceticism and draw connections between virulently negative Buddhist descriptions of sexual reproduction and women's role in it, on the one hand, and the embodied, affectively rich lives of premodern monastic women on the other.

\section{The Gender-Radical Potential of the South Asian Buddhist Rhetoric of Birth}

Though it permeates classical Buddhist literature, the fullest expression of the Indic Buddhist rhetoric of birth is an early-first-millennium Buddhist sūtra, originally composed in Sanskrit, that assembles various authoritative Buddhist statements about conception, gestation, and childbirth in one place. Different versions go by different names, but, for the purposes of this essay, I will call this textual tradition the Garbhāvakrānti-sūtra ("Descent of the Embryo Scripture"). The core of this tradition is an embryological narrative of human birth that evocatively describes the gestation of new life in the womb, week by week. ${ }^{2}$ The Garbhāvakrānti-sūtra survives in three Tibetan and three Chinese translations of what were, according to Robert Kritzer's philological history of this tradition, most likely four original Sanskrit versions. ${ }^{3}$ No Sanskrit version has survived, though apparent quotations do occur in several extant Buddhist scholastic works in Sanskrit. ${ }^{4}$ Quotations from or references to the text also appear in Chinese

2 This is quite unlike other Indic embryologies, which trace fetal development only month by month. See, for instance, Robert Kritzer, "Life in the Womb: Conception and Gestation in Buddhist Scripture and Classical Indian Medical Literature," in Imagining the Fetus: The Unborn in Myth, Religion, and Culture, eds. Vanessa Sasson and Jane Marie Law (New York: Oxford University Press, 2009), 73-90.

3 For a detailed history of the text, see Robert Kritzer, "Tibetan Texts of Garbhāvakrāntisūtra: Differences and Borrowings," Annual Report of the International Research Institute for Advanced Buddhology 15 (2012): 131-45; Robert Kritzer, "Garbhāvakrāntau ('In the Garbhāvakrānti'): Quotations from the Garbhāvakrāntisūtra in Abhidharma Literature and the Yogācārabhūmi," in The Yogācārabhūmi and the Yogācāras, ed. Ulrich Timme Kragh (Cambridge: Harvard University, Department of Sanskrit and Indian Studies, 2013), 728-71; and Robert Kritzer, Garbhāvakrāntisūtra: The Sūtra on Entry into the Womb (Studia Philologica Buddhica, XXXI. Tokyo: The International Institute for Buddhist Studies, 2014), 3-10.

4 Namely, the Abhidharmakośabhāṣya and Yogācārabhūmi. See Kritzer, "Garbhāvakrāntau," $749,751,754,757,761$ for a detailed analysis of specific passages. 
translations of yet other scholastic treatises. ${ }^{5}$ These various references and redactions allow Kritzer to propose that versions of the Garbhāvakrānti-sūtra were in circulation by the middle of the second century CE. ${ }^{6}$

As just mentioned, various Indian scholastic texts appear to quote either the Garbhāvakrānti-sūtra itself or shared source traditions about the birth process. Tibetan teachers and scholars also knew the sūtra. Additionally, it was a major source of embryological knowledge in the Tibetan medical tradition and is frequently cited in the embryology chapter of the seventeenth-century Tibetan medical scholar Desi Sangyé Gyatso’s important medical commentary, Baidurya nGonpo (The Blue Beryl). ${ }^{7}$ One or several versions of this text also had a role to play in Chinese Buddhist and Daoist treatments of the process of birth. ${ }^{8}$ In short, while not a famous Buddhist sūtra text in Western scholarship, the Garbhāvakrānti-sūtra was certainly well known in the learned circles of

5 Kritzer, "Garbhāvakrāntau" provides a superbly detailed study of quotations from the sūtra found in the various texts surviving in Chinese translation. For some observations regarding the relationship between the Yogācārabhūmi attributed to Asanga, other Yogācāra texts extant in Chinese, and the Garbhāvakrānti-sūtra, see Nobuyoshi Yamabe, "Parallel Passages between the Manobhūmi and the Yogācārabhūmi of Samgharakșa," in The Foundation for Yoga Practitioners: The Buddhist Yogācārabhūmi Treatise and Its Adaptation in India, East Asia, and Tibet, ed. Ulrich Timme Kragh (Harvard Oriental Series 75. Cambridge: Harvard University Press: 2013), 596-737. 6 Kritzer, Garbhāvakrāntisūtra, 3. The earliest Chinese translation, the "Womb-Dwelling Sūtra" (Pao-t'ai ching) by Dharmarakșa, which is based on a short version of the text, dates to either 281 or $303 \mathrm{CE}$. Two other translations were made during the Tang dynasty, one by Bodhiruci, the other by Yijing. The former was apparently based on a second version of the short "Descent of the Embryo," the latter on a longer version of the text. Two Tibetan translations, respectively based on Bodhiruci and Yijing's Chinese texts, were produced during the early ninth century in Dunhuang. The only Tibetan translation made from a Sanskrit original occurs in the Kșudrakavastu of the Tibetan Mūlasarvāstivāda-vinaya and also dates to the ninth century. The latter is the longest version of the text we have in any language. In 2014, Kritzer completed his exhaustive comparative study of all Chinese and Tibetan translations and produced a critical edition and translation of the Tibetan Kșudrakavastu text. In my study of this text, I rely upon Kritzer's edition as my primary source for this complex textual tradition, but I also use my own translation of the longer Dunhuang text (hereafter referred to as Tōhoku 57), the embryological portion of which has been published: Amy Paris Langenberg, "Fetal Suffering in the Descent of the Embryo Sūtra," in Buddhism and Medicine: A Sourcebook, ed. C. Pierce Salguero (New York: Columbia University Press: 2017), 41-47.

7 For Tibetan embryological theories, see Frances Garrett, "Ordering Human Growth in Tibetan Medical and Religious Embryologies," in Textual Healing: Essays on Medieval and Early Modern Medicine, ed. Elizabeth Lane Furdell (Leiden: Brill, 2005), 31-52 and Garrett, Religion, Medicine and the Human Embryo in Tibet (Abingdon-on-Thames: Routledge, 2008).

8 Jessey Choo, “That 'Fatty Lump': Discourses on the Fetus, Fetal Development, and Filial Piety in China Before the Eleventh Century CE,” Nan Nü 14 (2012): 177-221. 
premodern Buddhism as an authoritative source for the Buddha's teachings on embryology and the birth process - no small topic in Buddhist thought. Moreover, echoes of the themes and content of the garbhāvakrānti occur across premodern South Asian texts: for instance, in a passage from the Viṣnu Purāna, ${ }^{9}$ as a pallava of Kșemendra's Bodhisattvādānakalpalatā,${ }^{10}$ and even in an acerbic poem by the fifteenth-century bhakti poet Kabir. ${ }^{11}$

The Garbhāvakrānti-sūtra covers a range of related topics, including the appearance and behavior of the intermediate state of a being, various diseases of the womb, the necessary elements of conception, how the gender of the fetus is determined, the effect of good or bad past actions on one's physical appearance, the four levels of awareness a being can experience while occupying the womb ranked according to level of spiritual attainment, the sensory experiences of the newborn child (which are akin to torture), and the stages of life from infancy to old age. Its centerpiece, however, is a compelling embryological narrative in which the misadventures of the human fetus growing in the womb is told with great emotion and lush descriptive language.

9 Vișṇu Purāṇa 6.5.9-35. For a translation, see Wendy Doniger, ed., Norton Anthology of World Religions: Hinduism (New York: W. W. Norton \& Company, 2015), 270-271. For a similar motif, see Lakshmi Kapani, Garbhopanișad (Paris: A. Maisonneuve, 1976). Scholarly works on embryology and religious depictions of the fetus in premodern South Asia include Rahul Das, The Origin of the Life of a Human Being: Conception and the Female according to Ancient Indian Medical and Sexological Literature (Delhi: Motilal Banarsidass Publishers, 2003); Eva DeClercq, “The Great Men of Jainism in Utero: A Survey," in Imagining the Fetus: The Unborn in Myth, Religion, and Culture, eds. Vanessa Sasson and Jane Marie Law (New York: Oxford University Press, 2009), 33-54; André Couture, “The Story of Saṃkarṣaṇa’s and Kṛṣna’s Births: A Drama Involving Embryos," in Imagining the Fetus: The Unborn in Myth, Religion, and Culture, eds. Vanessa Sasson and Jane Marie Law (New York: Oxford University Press, 2009): 11-31; Martha Selby, "Narratives of Conception, Gestation, and Labour in Sanskrit Āyurvedic Texts," Asian Medicine 1, no. 2 (2005): 254-75; Frederick Smith, "Narrativity and Empiricism in Classical Indian Accounts of Birth and Death: The Mahābhārata and the Samphitās of Caraka and Suśruta," Asian Medicine 3, no. 1 (2007): 85-102; O. H. Wijesekera, "Vedic Gandharva and Pāli Gandhabba," University of Ceylon Review 3, no. 1 (1945): 73-107.

10 This literary collection of avadānas by the eleventh-century Kashmiri poet includes the Garbhāvakrāntyavadāna. See Amy Paris Langenberg, "Kșemendra's Garbhāvakrāntyavadāna through a Tibetan 'Looking-Glass,"” in In Vimalakirti's House: A Festschrift in Honor of Robert A. F. Thurman on the Occasion of His 70th Birthday, eds. Christian Wedemeyer, John D. Dunne, and Thomas Yarnall, Treasury of the Buddhist Sciences (AIBS) (New York: Columbia University Press, 2015), 119-130.

11 Kabir writes: "Mix red juice, white juice and air - a body bakes in a body. As soon as the eight lotuses are ready, it comes into the world. Then what's untouchable? Eighty-four hundred thousand vessels decay into dust, while the potter keeps slapping clay on the wheel, and with a touch cuts each one off. We eat by touching, we wash by touching, from a touch the world was born. So who's untouched? Asks Kabir” (Doniger, Norton Anthology, 404). 
According to the Garbhāvakrānti-sūtra's embryological narrative, the fetus begins as a viscous blob that hardens and gels like an egg yolk frying in a pan. It then develops five bubble-like protrusions and is blown up like a balloon. A hard wind blows open the nine orifices (one of the clues that the fetus is paradigmatically male). All of the dimensions and features of its body then manifest one by one, including fingers and fingernails, the system of channels that allow it to breathe and circulate blood, the skin and hair, and so forth. The continuing growth and development of the fetus, relentlessly impelled by one karmic wind after another, is a long, painful process characterized by growing sensory acuteness and ever-worsening mental and physical discomfort. Moreover, this unpleasant process takes place in the space of the human womb, which is described as a pus-andblood-filled cesspool. ${ }^{12}$

Many rhetorical evocations of the emotion of disgust ${ }^{13}$ pepper the text, culminating in long hyperbolic descriptions of the fetal experience of the womb:

Covered just by skin, a piled-up mass of excrement, growing hair and nails and teeth and body hair [. . .] (it sits,) [. . .] in (a place) rotten with the moistness of rancid snot and putrid, completely filled with fat, pus, the stench of sweat, saliva, bile, phlegm, lungs, small intestine, colon, spleen, bladder, and many varieties of filth, a dwelling for many thousands of types of worms that has two very foul-smelling openings, that has many bone holes and pore holes, and that is defiled by a mass of urine, brains, brain membrane, and marrow. Because menstrual fluids come forth each month it expands. Because the various foods of the mother are chewed fine by the two rows of teeth and swallowed in the throat, and the flavor of the food, which moistened from below with the filth of the wound that is the mouth and with spit and, filled with cranial membrane from above, is like vomit, enters inside from a hole in the umbilical cord, it grows and transforms [through the embryological stages] [. . .] and its arms, legs and jaws are wrapped in a thin skin covering. It wanders above and below in a foul-smelling, horrible-smelling, dark, slimy (place) which is like a toilet. ${ }^{14}$

Similarly drawn-out, equally hysterical descriptions of the womb experience are repeated five times in the text. If he survives the many difficult, bewildering, and unpleasant transformations in the hellish environment of the womb, finally managing to descend the birth canal intact without suffering dismemberment at the hands of a panicky midwife, ${ }^{15}$ the fetus then faces the ministrations

12 Langenberg, Birth in Buddhism; Langenberg, "Fetal Suffering."

13 For a fuller, theoretically-informed discussion of disgust in the Garbhāvakrānti-sūtra, see Langenberg, Birth in Buddhism, 75-93.

14 Kritzer's translation (Kritzer, Garbhāvakrāntisūtra, 90-91).

15 Kritzer has written on the midwife figure of the Garbhāvakrānti-sūtra. His unpublished paper, entitled “'Women who Know about That': Midwives and Wise Women in Buddhist Literature,” is available at https://www.academia.edu/38300468/For_Academia_revised_4.7_ 
of mothers, grandmothers, and nurses. These careless and ignorant women torture his raw and sensitive body, just as insects torture a wounded animal, in their efforts to bathe, swaddle, and feed him.

Although it may strike the modern reader as weirdly medical, clammily paranoid, and only marginally "religious," the Garbhāvakrānti-sūtra should not be regarded as an anomalous outlier text in the Buddhist corpus. Assertions that birth is the origin of human suffering, that the enlightened state is the state of being unborn (ajāta) or of eliminating the fetters that bring birth (uppattipatiliabhika-samyojana), and that the human birth process is fueled by ignorance and tainted by impurities are ubiquitous in the canonical tradition. ${ }^{16}$ For instance, sutta texts from the Pāli corpus place birth (jāti) at the head of a conventional list of experiences (along with aging and death) that define the unsatisfactoriness of existence. ${ }^{17}$ Texts such as the Aggaññ-sutta mock the putative purity of Brahmins with reference to their birth from human wombs (not the mouth of Brahmā!) and nourishment at human breasts, thereby positing birth as a universal equalizer and slayer of pretensions.

Discourses in which the Buddha explicates the doctrine of dependent arising (paticcasamuppāda) are particularly relevant as parallels and precursors to the Garbhāvakrānti-sūtra. In the "Great Discourse on Origination” (Mahānidāna-sutta), from the Dīgha-nikāya, the Buddha actually inaugurates his teaching on causality with the topic of birth itself: "If, Ānanda, there were no birth at all, anywhere [. . .] then, with the cessation of birth, could ageing-and-death appear?' 'No, Lord,' Ānanda replies. 'Therefore, Ānanda, just this is the root, the cause, the origin, the condition for ageing-and-death - namely, birth." 18 This text also illustrates several of the causal links of the dependent arising doctrine (consciousness and mind-and-form) phenomenologically in terms of the birth process: “'Ānanda, if consciousness, once it descended into the mother's womb, were to depart, would the name-and-form be reborn to this state?' 'It would not be, Lord.' 'Ānanda, if the consciousness of such a tender young boy or girl baby were to be severed, would name-and-form increase, grow, or develop?' 'It would not be, Lord.",19 The “Great Discourse on the Destruction

Submission_Women_who_Know_about_That_-_Midwives_and_Wise_Women_in_Buddhist_ Literature.docx. Accessed October 22, 2019.

16 See, for instance, Majjhima-nikāya (MN) i.163, i.167, i.139; and Saṃyutta-nikāya (SN) i.88.

17 See $M N$ i.48, ii.249; Dīgha-nikāya $(D N)$ ii.305; Vinaya i.10; and Añguttara-nikāya $(A N)$ i.76, iii.416.

18 Maurice Walshe, Maurice, Thus Have I Heard: The Long Discourses of the Buddha (London: Wisdom Publications, 1987), 224.

19 DN ii.63. My translation with reference to Walshe, Thus Have I Heard, 226. 
of Thirst" (Mahātaṇhāsainkhaya-sutta), from the Majjhima-nikāya, also elaborates on the phenomena of birth and human development within the context of its explication of dependent arising: "Monks, it is a threefold coincidence that results in the descent of the embryo (gabbhassāvakkanti). When there is the union of the mother and father, the mother is in a fertile period, and the gandhabba is present, this threefold coincidence results in the descent of the embryo. With great trepidation, the mother holds that embryo in her belly for nine or ten months, a heavy burden. When nine or ten months have passed, the mother gives birth to that heavy burden with great trepidation." 20 Thus, while the unfolding of phenomena that result from ignorance and craving is said to occur at all registers (human and nonhuman, physical and psychological, sentient and nonsentient, political and moral), the most immediately relevant of these to the Buddhist path, it seems, are the material processes of human embodiment within a woman's womb.

Later Indian scholastic authors from the Sanskrit Buddhist tradition, the textual milieu of the Garbhāvakrānti-sūtra, also appear to regard detailed knowledge of the birth process as highly relevant to travelers on the path to awakening. For instance, in a passage rich with material descriptions that are reminiscent of the medicalized language of the Garbhāvakrānti-sūtra, the Manobhūmi of the Yogācārabhūmi describes the ālayavijñāna (the "storehouse consciousness," a concept central to the Yogācāra school) as penetrating the sexually united couple's semen and blood, which has "coalesced in the mother's womb" and "bind[s] together as a creamy substance," and abides "as a single lump, like cooked-down milk being cooled." This charged entity - semen, blood, and intermediate-state consciousness - then experiences a small death and is instantly born again, this time with subtle and gross aspects of the sense faculties combined with and wedded to consciousness. "To the conscious being established in this state is affixed [the descriptor] 'conception' (pratisamdhi)," reads the text. ${ }^{21}$ Picking up a thread from the earlier sutta/sūtra tradition, the Abhidharmakośabhāṣya, attributed to Vasubandhu, articulates the doctrine of dependent arising in terms of anthropomorphic cycles of birth and death. The nidana (causal factor, the third of twelve), consciousness, is identified with the new embryo in the mother's womb at the time of conception. The embryo developing into a full-fledged fetus is used as an illustration of consciousness giving rise to name-and-form (nāmarūpa), and so forth through all twelve nidānas. ${ }^{22}$ Vasubandhu's text also contains an unidentified quote from the Garbhāvakrānti-sūtra describing what happens when the fetus dies

$20 M N$ i.265-266. My translation.

21 Yamabe's translation, with modifications (Yamabe, "Parallel Passages," 649-651).

22 Prahlada Pradhana, ed., Abhidharmakośa-Bhāṣyam (Patna: K. P. Jayaswal Research Institute, 1967), 130-133. 
and is cut out of the womb, which is "an excrement-hole, a cruelly foulsmelling dark pool of ordure, the home to many thousands of families of worms, permanently oozing, constantly in need of care, drenched in semen, blood, mucus, and impurities, decayed, steaming, and slimy, terrifying to behold," by a knife-wielding midwife. ${ }^{23}$

The sordid garbhāvakrānti tale of birth is most properly read against the Buddha's own famous birth story. These two tales of birth are twin aspects of the same Buddhist rhetoric of birth; in fact, they can be regarded as linked narrative traditions. The Sanghabhedavastu version of the Buddha's life from the Mūlasarvāstivāda-vinaya tradition, for instance, presents us with a picture of enlightened birth as an extraordinary exception to the squalid processes of embodiment generated from ignorance and desire. ${ }^{24}$ Whereas ordinary birth is violent, humiliating, disgusting, unpredictable, and undergone in ignorance the quintessential example of helplessness in relation to the impure and disgusting female reproductive body - the Buddha's birth is just the opposite in every respect. In the Sarghabhedavastu, the Buddha's conception, gestation, and birth are represented as regular, predictable, and dignified, hygienic and sweet-smelling, relying very little on Māyā's physical body, and undergone in a state of perfect awareness. ${ }^{25}$

In order to appreciate the distinctive nature of the Buddhist garbhāvakrānti discourse within the context of ancient South Asia and its potential as a "vector of social change," it is helpful to compare it with other influential Indic treatments of birth and the female reproductive body. The Garbhāvakrānti-sūtra places great emphasis on the violent and repugnant nature of the female reproductive body, and the antagonistic relationship between fetus and mother. One passage describes the developing fetus's experience as follows:

23 Pradhana, Abhidharmakośa-Bhāșyam, 130; Kritzer, "Garbhāvakrāntau,” 757.

24 The longest, most complete version of the Garbhāvakrānti-sūtra that exists, and the one that is closest in terms of its literary origins to the original Sanskrit, is also from the Mūlasarvāstivāda tradition, so text-historically close to the Sarighabhedavastu version of the Buddha's life. For the latter, see Raniero Gnoli and T. Venkatacharya, The Gilgit Manuscript of the Sanghabhedavastu: Being the 17th and Last Section of the Vinaya of the Mūlasarvāstivādin, vol. 1 (Roma: Istituto Italiano per il Medio ed Estremo Oriente, 1977).

25 The version of the Buddha's birth story that emphasizes the differences between his extraordinary birth and ordinary birth most dramatically is found in the Lalitavistara, which describes the fetal bodhisattva gestating inside of the ratnavyūha, a fragrant, softly lined, jeweled pavilion made of gemstones, sandalwood, and gold that protects the bodhisattva from the birth impurities of Māyādevī’s womb. Paraśurāma Vaidya, ed., Lalita-Vistara (Darbhanga: Mithila Institute of Post-Graduate Studies and Research in Sanskrit Learning, 1958), 47.11-14, 49.10-11. 
The fetus is located below the stomach and above the bowels. The fetus will be pressed down upon by the undigested matter and forced upward by the digested matter. It is like being bound in five places and then penetrated by the tip of a sharp wooden lance. If the mother eats a lot of food or too little food, the fetus suffers. Similarly, if the food is very oily, or very dry, or very cold, or very hot, or has a very salty flavor, or no flavor, or is bitter, or sour, or sweet - in all cases, if such food is eaten, the fetus will suffer. If the mother has sex, moves violently, runs, stays in a scary place, sits for a long time, sleeps for a long time, or jumps up and down - in all cases, the fetus will suffer. Nanda, you should understand that while in the womb the body is oppressed by various sufferings of this sort that are beyond description. ${ }^{26}$

The Buddhist characterization of the mother-fetus relationship as hostile stands in contrast, for instance, to the Caraka-samhitä's understanding of this relationship. In this roughly contemporaneous Âyurvedic text, the gestational relationship is epitomized by a "feeling of two-heartedness" (dvaihrdayya). Here, mother and fetus share an intimate affective bond because their two bodies are considered to be linked by channels that carry thoughts and feelings as well as life-sustaining nutrition. The mother expresses the child's needs and desires through her moods and cravings, thereby providing for and protecting her child. "Satisfying the mother's every desire is the same as satisfying the needs of the embryo," Caraka advises. "Therefore, it is prudent to diligently provide a pregnant woman with whatever she desires or needs."27

Discussions of female impurity in the Brahminic legal tradition are also a relevant point of comparison for the Buddhist garbhāvakrānti and related traditions. ${ }^{28}$ Although Buddhist critiques of Brahminic ritual categories and classical Buddhist teachings' replacement of the body with the mind as a primary locus of impurity has led many scholars of Indian Buddhism to attribute talk of female foulness in Buddhist contexts to Brahminic influence, a comparison of Brahminic legal sources with Buddhist sources reveal distinctly different rhetorics of female impurity. In general, Brahminic legal texts attribute female impurity to the god Indra's wrongdoing (not to the sins of women), treat female birth

26 Langenberg, "Fetal Suffering," 46.

27 CS Śārīrasthāna 4.15. My translation. Vaidya Jādavaji Trikamji Ācārya, ed., The Carakasamitā of Agniveśa (New Delhi: Munshiram Manoharlal, 1981).

28 For a fuller, theoretically informed discussion of blood impurity in premodern South Asia, see Amy Paris Langenberg, "Buddhist Blood Taboo: Mary Douglas, Female Impurity, and Classical Indian Buddhism," Journal of the American Academy of Religion 84, no. 1 (2016): 157-191. 
and menstrual impurity as temporary and washable, and frequently declare married women to be inherently pure. Baudhāyana Dharmasūtra 2.4.4, for instance, regards monthly menstruation as so powerfully purifying that women "never become sullied," even in the case of rape, abduction, or adultery. ${ }^{29}$ Vasiștha Dharmasūtra 28.8-9 declares wives to be so cleansed by the marriage ritual and their monthly menses that their purity surpasses the back of a cow and the feet of a Brahmin. ${ }^{30}$ By contrast, the garbhāvakrānti tradition and multiple other Indian Buddhist texts written from the perspective of male asceticism depict the impurity of women's bodies as the source of all human bodily impurity in general and a lifelong indelible state. According to the Garbhāvakrānti-sūtra, the womb is a "filthy, rotting, smoldering swamp,"31 "always putrid with semen, blood, filth, and pus," 32 a "foul-smelling, horrible-smelling dark, slimy (place) which is like a toilet." ${ }^{33}$ Echoing the Aggañña-sutta and paraphrasing, it would seem, the language of the garbhāvakrānti tradition, the important Indian philosopher Candrakīrti asserts, several centuries later, that all of us are equally impure by virtue of our squalid origins: "Someone before he was born lived inside his mother's womb - which is like an outhouse - between intestines and stomach. Like a dung worm, he was nourished by the fluid of her waste products. It is only from ignorance that he thinks 'I am pure." 34 Whereas Brahmin lawgivers regard the three-day prohibition on sex during menstruation as protection for the husband against Indra's sin, not the wife's own sin, and sex with an auspicious wife as pure by definition (except during menstruation and just after birth), the famous Nālandā monk Sāntideva quotes the Inquiry of King Vatsa of Udayana, mocking fools who, in having sex with a woman, "are infatuated like crows drawn to filth. Greedy for an idea of enjoyment, living in filth like worms, they are in Māra's domain [...] The Buddhas criticized women for being foul-smelling, like dung. Therefore, only lowly men have intercourse with women, who are lowly." 35 As this brief but representative sampling indicates, the rhetorical intensity of Buddhist texts on the topic of an indelible and primevally female impurity is a

29 Patrick Olivelle, ed. and trans., Dharmasūtras: The Law Codes of Āpastamba, Gautama, Baudhāyana, and Vasiștha (Delhi: Motilal Banarsidass, 2003), 257.

30 Olivelle, Dharmasūtras, 459.

31 Garbhāvakrāntisūtra (GS) 252.3-4. My translation.

32 Kritzer, Garbhāvakrāntisūtra, 91.

33 Kritzer, Garbhāvakrāntisūtra, 91.

34 Karen Christina Lang, Four Illusions: Candrakirti's Advice for Travelers on the Bodhisattva Path (New York: Oxford University Press, 2003), 180.

35 Charles Goodman, ed., The Training Anthology of Śāntideva: A Translation of the Sikșāsamuccaya (New York: Oxford University Press, 2016), 84-85. 
departure from, not continuous with or imitative of, Brahminic ritual taboos around female blood.

The Garbhāvakrānti-sūtra's articulation of a punitive physically repugnant feminine also contrasts dramatically with a more or less concurrent North Indian visual program of displaying gorgeous and inviting female auspiciousness in public religious spaces. ${ }^{36}$ For instance, from before the turn of the first millennium, sensuous, fecund women were regularly included in the sculptural programs of Buddhist stūpas. As the historian D. D. Kosambi has put it, "magnificent women in opulent but highly revealing costumes, and their handsome male companions, stretched unbroken from Gandhāra and Bhārhut to Ajanta and Amarāvati."37 These "magnificent women" commonly graced the gateways and outer walls, often in a śālabhañjikā or "branch bending" pose, and, scholars believe, may have performed an apotropaic function. ${ }^{38}$ The relationship between an obviously sexual śālabhañjikā figure and the erect flowering tree around which she twines - and which, it is implied, responds to her touch - is suggestive of her fecundity. Interestingly, śālabhañjikās are sometimes described as dohada (a Prakritized term with the same linguistic roots as dvaihrdayya) because of the heart connection they share with their tree companions. ${ }^{39}$ The śālabhañjikā motif comes to be closely associated with Māyādevī, the Buddha's mother, who is unfailingly represented as a graceful "branch-bender" in sculptural depictions of the Buddha's birth. Thus, even in certain Buddhist contexts, and in marked contrast to the Garbhāvakrānti-sūtra's view, women's fertility and sexuality are generally auspicious (a female-inflected wealth-and-power-generating ritual property).

Another productive point of contrast between the primary message of the Garbhāvakrānti-sūtra and contemporaneous Buddhist culture in premodern India concerns monks' involvement in the ritual protection of pregnant women

36 For a fuller discussion of auspiciousness in Indian Buddhism, see Langenberg, Birth in Buddhism, 94-132.

37 D. D. Kosambi, Ancient India: A History of Its Culture and Civilization (New York: Pantheon Books, 1966), 179.

38 Claudine Bautze-Picron, "The Lady under the Tree - A Visual Pattern from Māyā to the Tārā and Avalokiteśvara," in The Birth of the Buddha, eds. Cristoph Cueppers, Max Deeg, and Hubert Durt (Lumbini: Lumbini International Research Institute, 2010), 193-237; Vidya Dehejia and Thomas B. Coburn, Devi: The Great Goddess: Female Divinity in South Asian Art (Washington, DC: Arthur M. Sackler Gallery, Smithsonian Institute in association with Mapin Publishing, Ahmedabad and Prestel Verlag, Munich, 1999), 369-77.

39 Dehejia and Coburn, Devi, 370; Gustav Roth, “The Woman and Tree Motif: ŚālabhañjikāDālamālikā in Prakrit and Sanskrit Texts with Special Reference to Śilpaśāstras Including Notes on Dohada," Journal of the Asiatic Society 23, no. 1 (1957): 91-44. 
and young children. ${ }^{40}$ Aimed, at least in its near frame, at the cultivation of aversion in male ascetics, the Garbhāvakrānti-sūtra is frankly and overwhelmingly negative toward pregnancy and childbirth as a project of human becoming. Addressing his handsome, wealthy, and sexually fulfilled half-brother, Nanda, in hopes of convincing him to leave behind his beautiful young wife (with whom Nanda presumably intends to father sons) and devote himself to the monastic life, the Buddha of the Garbhāvakrānti-sūtra comments:

Nanda, I do not praise the conception of a life even a little bit. I do not praise the conception of a [new] life for even one moment. Why is that? The conception of life is suffering. In the same way that even a little vomit stinks, Nanda, even the momentary conception of a tiny life is suffering. Nanda, a being for whom there is arising of material form, establishment [in the womb], development, emergence [from the womb], sensation, intellect, volitions, consciousness, indeed, any being at all that is established, develops, and emerges, is miserable. Abiding [in the womb] is sickness. Emerging [from the womb] is old age and death. Nanda, for this reason, what profit is there for the one lodged in the womb, craving life so deeply? ${ }^{41}$

As was argued above, this perspective is not unique to the Garbhāvakrāntisūtra, although it is expressed there with particular force and verve; indeed, statements regarding the inferiority of a life centered around reproduction and the miserable nature of embodied existence are ubiquitous in South Asian Buddhism.

Nevertheless, textual and material sources give evidence that Buddhist ascetics and ritualists were just as involved in promoting conception, safeguarding pregnancy, and protecting very young children as their non-Buddhist counterparts. In her important work on Jain ritualism, Phyllis Granoff has suggested that Buddhists and Jains did reject rituals performed for the purpose of procuring children, at least in theory, as part of their efforts to distinguish themselves from Vedic Hindus, but that ritual practice is not a stable marker of sectarian identity and we should not be surprised to find descriptions of Jains (or Buddhists) performing the same rituals they reject in principle. ${ }^{42}$ Indeed, minor rules from the vinaya tradition studied by Gregory Schopen mention (either to proscribe or allow) monks' and nuns' participation in certain rituals that promote fertility. ${ }^{43}$ A Buddhist text from

40 For a full treatment of Buddhist fertility rituals, see Langenberg 2013.

41 GS 251.3-12. My translation.

42 Phyllis Granoff, "My Rituals and My Gods: Ritual Exclusiveness in Medieval India,” Journal of Indian Philosophy 29, no. 1 (2001): 109-34.

43 Gregory Schopen, "The Urban Buddhist Nun and a Protective Right for Children in Early North India," in Pāsādikadānam: Festschrift für Bhikkhu Pasadika, ed. M. Straube (Marburg: Indica et Tibetica Verlag, 2009), 359-380. 
the classical period called the Abhisamācārikā, studied by Karen Muldoon-Hules, contains dedicatory verses to be recited at marriages and births, indicating that monks attended householder life-cycle rites. ${ }^{44}$ The cult of the Buddhist protectress, Hārītī, often found in the porticos or side shrines of Buddhist monasteries, was widespread in northern India during the period in which the Garbhāvakrānti-sūtra was composed and for centuries after. Inscribed images and the reports of the Chinese pilgrims Yijing and Xuangzang give evidence of her importance in local cults of fertility and child protection and monks' ritual mediation between the goddess and the laity. ${ }^{45}$ Later sources from Dunhuang also give evidence of monastic involvement in rituals of fertility and child protection. For instance, a ninth- or tenth-century spell book written in Tibetan and studied by Sam Von Schaik mentions "thread-winding magic" to cure "women with inverted wombs," 46 as well as another, more elaborate ritual involving a mandala and meditative visualization to place a child in a woman's womb or protect her life after birth. ${ }^{47}$ Indeed, so pervasive were concerns about fertility, so acknowledged and supported the desire for healthy children, that Buddhist monks appear always to have routinely practiced ritual interventions in the reproductive lives of householders. While monks' fecundist ritual activities could potentially be a source of doubt about the social impact of the Buddhist birth discourse epitomized by the Garbhāvakrānti-sūtra, the fact of these seemingly routine clerical interventions in matters of fertility and childbirth also underscores that discourse's profoundly radical nature and its disruptive potential for women should they come to know of it.

Postmodern and postcolonial developments in feminist thought have been helpful in their insistence that gender and gender-based oppression are discursively constructed and historically specific experiences. ${ }^{48}$ Indeed, if, in tacitly

44 Karen Muldoon-Hules, "Avadānaśataka: The Role of Brahmanical Marriage in a Buddhist Text," in Women in Early Indian Buddhism: Comparative Textual Studies, ed. Alice Collett (New York: Oxford University Press, 2014), 192-220.

45 Samuel Beal, ed., Si-Yu-Ki, Buddhist Records of the Western World (Calcutta: Susil Gupta, 1958); Richard Cohen, "Nāga, Yakșinī, Buddha: Local Deities and Local Buddhism at Ajanta," History of Religions 37, no. 4 (1998): 360-400; Anna Maria Quagliotti, “An Inscribed Image of Hārìtī in the Chandigarh Government Museum and Art Gallery," Silk Road Art and Archaeology 6 (1999): 51-60.

46 Sam Van Schaik, “A Tibetan Book of Spells,” Early Tibet: Notes, Thoughts, and Fragments of Research on the History of Tibet (blog), February 2, 2009, https://earlytibet.com/2009/02/19/ a-tibetan-book-of-spells/. Accessed October 22, 2019.

47 Sam Van Schaik, “A Tibetan Book of Spells” (unpublished manuscript, accessed September 4, 2018), pdf file.

48 For detailed treatments of postcolonial and poststructural feminist thought in relationship to female Buddhist monasticism, see Langenberg, Birth in Buddhism, 1-25; and Amy Paris Langenberg, 
assuming that the social category "woman" flows organically from biology, one fails to examine in detail the complex processes by which womanhood was continuously and locally negotiated and performed in ancient India, one is likely to produce a purely flat and negative reading of the garbhāvakrānti tradition, a mere surface judgment that this way of thinking is rather hard on women and their female bodies. However, as feminist thinkers and historians have amply illustrated, misogynistic or androcentric discourses do not always translate straightforwardly into misogynistic or androcentric realities, and egalitarian discourses rarely translate into social equality. Moreover, various kinds of female power, autonomy, and freedom emerge even in patriarchal social environments. ${ }^{49}$ While apparently hard on women, the Garbhāvakrānti-sūtra is harder on coveted South Asian ideals of womanhood: namely, the auspiciousness of married women, the cyclical purity/impurity of menstruating women, and the sexual desirability of young women. In the Garbhāvakrānti-sūtra and related traditions, the reproductive woman is perennially ugly, she is perennially impure, and her fertility is no longer auspicious or apotropaic, but a passageway to death. This ascetic dismantling of mainstream norms of female virtue certainly posed a risk that women under its influence would lose whatever social influence, ritual power, and robust identity they might otherwise have garnered within a conservative patriarchal system that mainly valued their potential as breeders and sexual partners. But the Buddhist critique of birth also inserted a question mark, a potent unknowing, into the identity category "woman": if the powerfully inauspicious, abject, and impure woman-icon of the Garbhāvakrāntisūtra renders all properties at the heart of womanhood - beauty, auspiciousness, purity - impossible or a lie, what, then, is a woman? In a world in which everyone seemed to agree about how important and valued women were as sexualized persons and childbearers, the thoroughgoing critique of female beauty, auspiciousness, and purity that Buddhist ascetic discourses such as the Garbhāvakrānti offered would have been a portal into another world for female seekers and questioners, however frightening and risky. I argue that monastic women stepped eagerly

“An Imperfect Alliance: Feminism and Contemporary Female Buddhist Monasticisms," Religions 9, no. 190 (2018): 1-24.

49 For a fascinating example of the complexities of ancient gender, see Alice Collett's research on the Sātavāhana queen Nāgaṇnikā. Nāgaṇnikā is featured in an inscription at Nāneghāt that apparently describes her sponsorship and performance of Vedic rituals, something she, a woman, was not supposed to be able to do, according to scriptural orthodoxy. Alice Collett, "Reimagining the Sātavāhana Queen Nāgaṇnikā," Journal of the International Association of Buddhist Studies 41 (2018): 329-358. 
into, discovered a rare sort of freedom within, and built new social worlds inside this imaginative space of questioning and unknowing.

Material and textual sources give evidence that nuns were a significant and thriving sector of premodern Buddhist communities. Preeminent early nuns are lauded and their accomplishments listed in canonical texts preserved both in Pāli and Chinese. ${ }^{50}$ Up through the fourth or fifth centuries CE, inscriptions indicate that nuns were active donors at sites such as Sāñchī, on a par with monks, ${ }^{51}$ and may have been powerful enough to compete with monks' communities for resources. ${ }^{52}$ Manuscript colophons and illustrations of female donors indicate that Buddhist nuns were and continued to be active as donors and sponsors well into the medieval period. ${ }^{53}$ Inscriptions also describe nuns as the direct students of male teachers, and as themselves lineage teachers of other women. 54

Material and textual evidence that women were teachers, patrons, and respected practitioners of the Dharma provides an important framework for thinking historically about the premodern nun community, but tells us less about

50 Anālayo, "Anguttara-nikāya/Ekottarika-Āgama: Outstanding Bhikkhunīs in the EkottarikaĀgama," in Women in Early Indian Buddhism: Comparative Textual Studies, ed. Alice Collett (New York: Oxford University Press, 2014), 97-115; Anālayo, "Saṃyutta-nikāya/SaṃyuktaĀgama: Defying Māra-Bhikkunīs in the Sampyukta-Āgama," in Women in Early Indian Buddhism: Comparative Textual Studies, ed. Alice Collett (New York: Oxford University Press, 2014), 116-39; Kathryn R. Blackstone, Women in the Footsteps of the Buddha: Struggle for Liberation in the Therigatha (Surrey: Curzon Press, 1998); Alice Collett, "Therīgāthā: Nandā, Female Sibling of Gotama Buddha," in Women in Early Indian Buddhism: Comparative Textual Studies, ed. Alice Collett (New York: Oxford University Press, 2014), 140-159.

51 Nancy Barnes, "Nuns at the Stūpa," in Women's Buddhism, Buddhism's Women, ed. Ellison Banks Findly (Somerville, MA: Wisdom, 2000), 17-36; Matthew D. Milligan, "The Economic Power of Women in Early South Asian Buddhism," The Indian Economic and Social History Review 56, no. 1 (2019): 1-25; Kumkum Roy, "Women and Men Donors at Sanchi: A Study of Inscriptional Evidence," in Position and Status of Women in Ancient India, ed. L. K. Tripathi (Varanasi, 1988), 209-23; Gregory Schopen, "On Monks, Nuns, and 'Vulgar' Practices: The Introduction of the Image Cult into Indian Buddhism," in Bones, Stones, and Buddhist Monks: Collected Papers on the Archaeology, Epigraphy, and Texts of Monastic Buddhism in India (Honolulu: University of Hawai'i Press, 1997), 238-57.

52 Gregory Schopen, "The Suppression of Nuns and Ritual Murder of Their Special Dead," in Buddhist Monks and Business Matters: Still More Papers on Monastic Buddhism in India (Honolulu: University of Hawai'i Press, 2004), 329-59.

53 Jinah Kim, “Unheard Voices: Women's Roles in Medieval Buddhist Artistic Production and Religious Practices in South Asia," Journal of the American Academy of Religion 80, no. 1 (2012): 200-232.

54 Alice Collett, "Women as Teachers and Disciples in Early Buddhist Communities: The Evidence of Epigraphy,” Religions of South Asia 9, no. 1 (2015): 28-42. 
the social and political dynamics or the affective texture of their daily embodied lives as ascetic women. Legal literature (vinaya) associated with premodern nun communities affords a more intimate glimpse of women's lives in what I am calling the radical moral-social space of female monasticism, a space in which womanhood was being renegotiated. Textual scholarship on vinaya materials has shown that female monastic culture was distinctive ${ }^{55}$ and, though problematic for the male community in certain ways, legally accommodated by monastic authorities nonetheless. ${ }^{56}$ Here I attempt to draw on texts from vinaya literature related directly to the affective and the embodied in order to make more visible a few aspects of the moral-social space of renunciation that would have been important for nuns' sense of self and daily experiences as Buddhist ascetics: namely, menstruation and affective bonding. In doing so, I hope to also make visible a delicate line of connection between the antifecundist imaginary of the Garbhāvakrānti-sūtra and the alternative moral-social environment of premodern female Buddhist monasticism.

\section{Menstruating in the Nunnery}

Menstruation is a disciplinary issue unique to the nun community, and one operating against the previously referenced background of the South Asian ritual and symbolic tradition of venerating and abominating female blood. All of the sectarian vinaya traditions contain texts that promulgate rules regarding the management of monthly bleeding. For instance, bhikṣuṇi prakīrnaka 15 from the Prakritized Sanskrit Mahāsānghika-lokottaravādin Bhikṣuṇi-vinaya reads:

The lord was staying at Śrāvastī. The nuns got their menstrual periods month after month. The blood ruined the bedding and seating. Mahāprajāpatī Gautamī briefed the lord about this matter. "Is it suitable, lord, to wear a cloth shaped like an axle pin (änicolaka) for the purpose of protecting the bedding and seating?" The lord replied, "A cloth shaped like an axle pin is suitable. The one whose period has come and whose blood flows is to wear a cloth shaped like an axle pin, that is, a bundle of scraps. Pushing

55 Damchö Diana Finnegan, "For the Sake of Women, Too": Ethics and Gender in the Narratives of the Mūlasarvāstivāda Vinaya (PhD diss., University of Wisconsin-Madison, 2009); Amy Paris Langenberg, "Mahāsānighika-Lokottaravāda Bhikṣuṇi Vinaya: The Intersection of Womanly Virtue and Buddhist Asceticism," in Women in Early Indian Buddhism: Comparative Textual Studies, ed. Alice Collett (Oxford: Oxford University Press, 2014), 80-96.

56 Shayne Neil Clarke, Family Matters in Indian Buddhist Monasticisms (Honolulu: University of Hawai'i Press, 2014); Mari Johanna Jyväsjärvi, Fragile Virtue: Women's Monastic Practice in Early Medieval India (PhD diss., Harvard University, 2011). 
it in too shallowly is not suitable but neither is pushing it in too deeply in order to dispel the passion of desire. On the contrary, it should be pushed into the orifice (vranamukha; literally, "mouth of the wound") loosely. Whichever nun inserts it too deeply, or too shallowly, in that way slaking her lust, commits a gross sin." This is said regarding the matter of the cloth shaped like an axle pin. ${ }^{57}$

The Pāli-vinaya also contains a prescription to wear the ānicolaka..$^{58} \mathrm{~A}$ roughly corresponding prāyaścittika rule from the Mūlasarvāstivāda-vinaya prescribes a cloth tied on with a string, but not one shaped "like an axle pin." 59 Another rule in the Pāli-vinaya says, "When a nun uses the household cloth without relinquishing it, it is an offense requiring expiation." ${ }^{60} \bar{A}$ vasathacivara, the relevant Pāli term here, is translated here as "household cloth" following Hüsken, who argues that $\bar{a}$ vasatha refers to a roadside lodging where ascetics stay overnight. Hüsken also suggests that the âvasathacivara is a publicly kept menstrual cloth to be used by visiting nuns for three nights, then washed on the fourth and relinquished to another nun. ${ }^{61}$ The idea of the "household cloth" as such is missing from the Mūlasarvāstivāda-vinaya, though there is a rule about relinquishing the communally owned menstrual cloths. ${ }^{62}$ Similarly, the Mahāsānghika-lokottaravādin Bhikșuṇi-vinaya does not reference the "household cloth" as such, although it does mention relinquishing communally owned menstrual rags in a series of texts about where and how nuns should wash their menstrual cloths. ${ }^{63}$

A passage from Gunaprabha's Vinayasūtra, an important vinaya digest from the Mūlasarvāstivāda tradition, gives the Sanskrit term for the special cloth worn by menstruating Mūlasarvāstivāda nuns as rajaścoḍa ("that which

57 Gustav Roth, ed., Bhikșuṇi-Vinaya Including Bhikșuṇi-Prakīṇaka and a Summary of the Bhikșu-Prakīrnaka of the Ārya-Mahāsāṃghika-lokottaravādin (Patna: K. P. Jayaswal Research Institute, 1970), 309, §268.

58 I. B. Horner, The Book of the Discipline (Vinaya-pitaka) (1938-1966; repr., Bristol: The Pali Text Society, 2012-2014), 5:374.

59 Derge Kangyur, 'dul ba, ta 299a7-299b6.

60 Vinaya sutta-vibhangha, pācittiya 47. My translation, with reference to I. B. Horner's translation and Ute Hüsken, “Pure or Clean?” Traditional South Asian Medicine 6 (2001): 85-96. Hüsken further proposes that âvasathacivara is, at least in the context of this rule, a nod to Brahminic practice, which requires the menstruating wife to use a "stained cloth" (malavadvāsas) for three days and wash it on the fourth, signaling to her husband the return of her sexual availability (Hüsken, "Pure or Clean?” 89-90).

61 Hüsken, "Pure or Clean?” 86-87.

62 Prāyaścittika 171 at Derge Kangyur, 'dul ba, ta 299b6-300a6. My translation.

63 Prakīṇaka 18 at Roth, Bhikṣuṇi-vinaya, 310, §271. See Langenberg, "MahāsānighikaLokottaravāda," 92-3 for a translation of this series of rules. 
conceals the menstrual flow"). ${ }^{64}$ Tibetan translators rendered this term sme gab, literally, "a cover for sorrow," but the story from the canonical commentary accompanying the relevant prāyaścittika rule hints at the possibility that the nuns themselves may have chosen to understand and experience their menses differently than some others in their social environment:

\begin{abstract}
For women, every month blood trickles out due to the degenerative force of previous karma. Because of this, the lord advised (nuns) to wear a special cloth (sme gab) for concealing the menstrual flow. At the time he said to "keep a special cloth," [the Lord knew] it was sure to fall if [a nun] put it on and walked, so at the same time he instructed [nuns to] "keep a special cloth," he [also] said to "attach it with a string." Because nobody stopped her, Sthūlanandā went out to beg for alms with blood trickling down her calf. Brahmins and householders, seeing her, asked, "Venerable lady, why is there blood on your calf?" She answered, "If you don't know, ask your mother! Ask your sister! Ask your daughter!" "You insult all of our homes!" they complained, muttering and recriminating. At that time, the nuns told the lord, and the lord [. . .] established a further precept: "If nuns don't keep a special cloth, it is an offense." Even then, Sthūlanandā said, "What is called a 'special cloth' (sme gab) is a cover for the unhappiness of women. What if I don't wear one?" [The lord said,] "If you don't acquire one, 'it is an offense,' as stated before."65
\end{abstract}

Here, Sthūlanandā seems to perform what amounts to an act of political theater in the streets of the town, then produces a brief, sardonic commentary on the social meanings and uses of female blood and the heavy-handed intrusions of men into women's management of their own bodies. Ultimately, she resists even the interventions of the Buddha himself. The Mahāsānghika-lokottaravādin prakīnaka rule referenced above also includes some commentary on nuns' use of menstrual technology when it cautions against "pushing it in too deeply" in order to "dispel the passion of desire." This comment appears to be an intratextual reference to definitions of sex as penetrative, as found in pāräjika 1, and may reflect the disciplinary concerns of monastic lawyers or senior women in the community.

Small differences between vinaya traditions on the subject of menstruation can be taken as evidence of Buddhist communities making adaptations in response to practical problems within the community and social pressures coming from the wider social environment. It seems that female Buddhist monastic communities formally incorporated a range of technologies into their disciplinary

64 Vinayasūtra 2.2343. "Vinayasutra. Preliminary transliteration of the ms. found in Tibet by Rahula Sankrityayana,” Göttingen Register of Electronic Texts in Indian Languages (GRETIL), accessed July 29, 2019, www.sub.unigoettingen.de/ebene_1/fiindolo/gretil/1_sanskr/4_rellit/ buddh/vinsutrc.txt.

65 Derge Kangyur 'dul ba, ta 299a7-299b6. 
regime - the ānīcolaka, the āvasathacīvara, and the rajaścoḍa - all different from the malavadvāsas ("stained cloth") of Brahminic menstrual law. As is customary in vinaya writings, these innovations are attributed to the Buddha; however, from a historical point of view, the Buddha is not likely to have been responsible for them. Male monastic lawyers may have conceived and handed down these provisions for nuns' monthly bleeding independently of the nuns' input. Given their much greater experience with menstrual hygiene and the politics of female blood from a woman's perspective, however, it seems far more likely that the nuns developed practical and socially appropriate solutions to the problem of monthly bleeding themselves, perhaps in consultation with the male sangha. These practices would then have been codified by monastic lawyers and included in the monastic disciplinary canon.

The Mahāsāṅghika-lokottaravādin prakīṇaka rule referenced above, whose narrative framing is limited to the statement that menstruating nuns "ruined the bedding and seating," is focused mainly on practical and moral management, not derogatory representations of gender, worry about blood taboos, or the venting of male sexual cathexis. In general, vinaya passages on menstruation are practical, straightforward, and include little engagement in gendered symbolism, or, notably, the poetics of disgust, especially compared to other classical Buddhist texts in which female blood is mentioned. The Mūlasarvāstivāda passage cited above, describing Sthūlanandā's brassy behavior and salty commentary, is perhaps an exception to the practical tone of most vinaya menstruation texts, but there, by my reading, it is the perspective of women, not the anxiety of elite men, that is made visible. Where the issue of blood impurity is raised, as in, for instance, rules proscribing washing out menstrual rags at public bathing areas, the concern seems to center on lay rather than monastic anxiety regarding the management of impurity. In general, the tone of menstrual texts in the vinaya stands in marked contrast to the ritual awe expressed in the Brahminic tradition and the exceptionally robust tradition of negativity toward the reproductive female body (with all of its oozing fluids) found in Buddhist texts such as the Garbhāvakrāntisūtra. They are remarkable in their unremarkableness, affording a glimpse, I suggest, of a female monastic culture that situated itself outside of androcentric South Asian traditions of venerating and abominating female blood. Thus, with regards to menstruation, ancient nuns did not necessarily align their bodily regimes and self-understanding with the concerns of elite male priests and ascetics, a radical social reality in and of itself. 


\section{Having Friends in the Nunnery}

Another interesting vinaya text from the Mahāsānghika-lokottaravādin tradition illuminates a further dimension of the moral-social space unique to premodern female Buddhist monasticism, a field of moral becoming made ready, I would suggest, by Buddhist antifecundist discourses such as the Garbhāvakrānti-sūtra that first clear and purify through a process of slash-and-burn. In an imaginative realm in which heterosexual reproductivity is polluting, inauspicious, and ugly, affective connection between people - let's call it love - puddles in places other than the heteronormative. Female monasticism, with its communal living structures and ethical self-distancing from heterosexual marriage, was apparently an arena within which affectionate relationships between women could develop and thrive, although not without perceived risk. Sanghātiśeșa $17^{66}$ of the Mahāsānghika-lokottaravāda bhikșuṇi-vinaya criticizes two nuns in Śrāvastī for "spending time together intimately (samrșță viharanti) mingled in body (kāyikena samsargeṇa)" and "mingled in speech (vācikena samsargeṇa).” Feeling that they are guilty of collusion, the other nuns criticize their relationship and living arrangement, eventually reporting them to the Buddha. The Buddha rules that two nuns shall not spend time together intimately "concealing one another's faults (anyonyasyāvadya-praticchādikā)."

It is not clear whether this text responds only to the risks to discipline of a close emotional and social coupling between nuns, or also indirectly addresses sexual intimacy between nuns. The rule itself emphasizes the concealing of faults as well as the fact of spending time intimately mingled in body and speech. The Chinese translation of the Mahāsānghika bhikṣuṇi-vinaya does give

66 Roth, Bhikṣunī-vinaya, 155-56, §270. The sanghātiśeșa are the second category of rules in the prātimokșa and are therefore second in severity. There are two types of sanghātiśeșa rules: one type that goes into effect immediately, and another that goes into effect only after three admonitions. This rule is of the second type. Transgressions of this type require a formal meeting of the community and a fortnight of mānatva discipline before the transgressing nun can be rehabilitated. Mānatva discipline is a penance imposed after the varșa retreat and including, as part of its ceremonial, a formal show of respect to the community of monks (or nuns).

67 The Kāmasūtra uses samsrșțta at one point specifically with reference to a young girl's intimate relationship with a nun. The nun is suggested to be a good candidate for advancing a naive girl's sexual education (1.3.14). In other places in the Kāmasūtra, it is clearly used to denote sexual intimacy $(1.5 .8,1.5 .8,1.5 .16,2.8 .29)$. In other places there, it merely connotes close association, but not necessarily of the sexual kind. See "Vatsyayana, Kamasutram," Göttingen Register of Electronic Texts in Indian Languages (GRETIL), accessed July 29, 2019, http://gretil.sub.unigoettingen.de/gretil/1_sanskr/6_sastra/6_kama/kamasutu.htm; Wendy Doniger and Sudhir Kakar, eds., Kamasutra (New York: Oxford University Press, 2002). 
some detailed information on this rule's nidāna (introductory frame story) regarding the nature of these two nuns' relationship. In Hirakawa's translation, "'To be close together in action"68 [i.e. kāyikena samsargena] means: to sleep together on a couch, ${ }^{69}$ to sit together on a couch, to eat from the same bowl, to put on each other's robes, ${ }^{70}$ to go in and out together. 'To be close in speech' [i.e. vācikena samsargena] means: to speak with a defiled and passionate mind." "71 This explanation is missing from the Sanskrit text, even though both are of Mahāsānghika derivation.

The Pāli and Dharmaguptaka versions of this rule seemingly displace the emphasis further from any suggestion of intimacy to the problem of collusion in other forms of nonvirtuous behavior. ${ }^{72}$ The Pāli text specifies that the two who "live in company" (Horner's tepid translation of the Pāli samsațthā viharanti) are pupils of the famously transgressive nun, Thullanandā, are of "evil habits, evil repute, of evil ways of living" and are in the practice of concealing one another's faults. ${ }^{73}$ The Pāli text does not include the phrase "with mingled body" or "with mingled voice," nor does it include any details about what "living in company" (as Horner translates it) actually means. The Dharmaguptaka version (translated by Heirman) is similar to the Pāli in its emphasis on the evil reputations and habits of the two nuns, which they conceal from the larger sangha while living together "in each other's community."74 The Dharmaguptaka

68 Akira Hirakawa, Monastic Discipline for the Buddhist Nuns: An English Translation of the Chinese Text of the Mahāsāmghika-Bhikșuṇi-Vinaya (Patna: Kashi Prasad Jayaswal Research Institute, 1982), 176. Hirakawa translates a word as "action" that usually means "body" (shen). I am indebted to my colleague, Andrew Chittick, for his generous help with exploring the Chinese parallels of these texts. All following notes on Chinese terms are based on personal communication with Chittick.

69 The word Hirakawa translates as "couch" is really a bed, as it is where one sleeps.

70 The reference here is to sharing clothes, not necessarily to dressing one another.

71 The two Chinese words used as descriptors here mean "contaminated" and "defiled" or "dirty." They do not literally denote passion.

72 According to Andrew Chittick (personal communication), the language in the Dharmaguptaka is sharper than in the parallel Mahāsānghika passage. For instance, the word that is used in the latter tradition for what is being covered up or concealed means "transgression" or "fault" (guo), whereas in the Dharmaguptaka passage, the word used for what is being covered up or concealed is "crime" (zui).

73 Horner, The Book of the Discipline, 3:207.

74 Ann Heirman, Rules for Nuns according to the Dharmaguptakavinaya (Delhi: Motilal Banarsidass Publishers, 2015), 2:360-367. The Chinese term used here connotes a family-like relationship (qin) and does not have a negative connotation. This tradition also mentions the influence of Thullanandā (Sthūlanandā) on these two nuns' living arrangement (Heirman, Rules for Nuns, 2:368). 
text also omits any specific mention of bodily merging. It does, however, provide some commentarial unpacking of what, exactly, these two wayward nuns are supposed to be getting up to. Apparently, they "make fun together, often to incite each other."75 They also plant flowering trees, pluck flowers, make garlands, and "walk around [with garlands]." They also sit "together with men or boys of the village," sometimes on the same bed; they drink and eat from the same receptacle; they sing, dance, act, play instruments, adopt silly positions; and so forth. ${ }^{76}$

There are some internal contextual clues to what might be implied or understood but not explicitly said in the Mahāsānghika-lokottaravādin version of sañghātiśeșa 17. For instance, the Mahāsāṅghika-lokottaravādin version of number 7 of the bhikṣuṇi pārājika rules (rules entailing defeat) also concerns concealing the faults of others. In the nidāna of this rule, the nun Kāli is given a young girl to raise and teach by a lay family from the Licchavi clan with the understanding that they will provide material support to Kālì. This young girl grows into a young woman under Kālī's care but, being of a passionate nature and harassed by mental impurities (kleśas), she does not desire to go forth. Kālī advises her, "Daughter, householders suffer. According to the lord, desire (kâma) is similar to a coal and cow-dung fire. What use to you is being a householder?" Privately, Kālī thinks, "if she runs away then my benefits and hospitality will come to an end." Unable to endure her mental defilements, Kālī's young charge becomes "mixed up" (miśri-bhūtā) with ascetics and monastic servants (ārāmikaparivrājaka). Her womb is filled; her stomach becomes big. She is expelled by the nuns. When Kālì confesses that she had encouraged her young charge to stay in the monastic community in order to protect her own access to requisites, the Buddha establishes the pāräjika that nuns should not conceal the serious faults of others. $^{77}$

In both cases, sañghātisesa 17 and pārājika 7, words that connote mixing or merging or union or intimacy are used to describe problematic forms of relationships. The heterosexual nature of this problematic relationship is clear in the päräjika rule, as the Licchavi girl becomes pregnant. In the case of the sanghātiśeșa rule, mention of samsı̣șța and kāyika samsarga could also potentially be taken to connote sexuality. For instance, both are used in kāmaśāstra

75 Heirman, Rules for Nuns, 2:365.

76 Heirman, Rules for Nuns, 2:365. Many of these actions are specifically proscribed elsewhere in the vinaya. See, for instance, a prakirnaka text about making garlands (Hirakawa, Monastic Discipline, 402). Only the detail about eating and drinking from the same receptacle resembles the details given in the Chinese Mahāsānghika text.

77 Roth, Bhikșuṇi-vinaya, §131, 92. 
literature to indicate sexual intimacy. ${ }^{78}$ In the sanghātiśeșa case, of course, any physical intimacy that is hinted at is between two women, not between a woman and man. ${ }^{79}$

Pācattika 86 of the Mahāsānighika-lokottaravādin Bhikṣuṇi-vinaya, which resembles the pārājika rule concerning the nun Kālī, adds further complexity to the picture. ${ }^{80}$ In this rule, the nun Kāli initiates her charge at the pravrajyā ordination level. The young female novice becomes intimate (samsșștā) with householders and mendicants, causing the Buddha to lay down the rule that if a nun becomes intimate with a householder or mendicant, even a novice monk or layperson attached to the temple, for a day or a moment, it is a pācattika offense (a level of offense requiring confession and expiation). The word-for-word commentary of this rule supplies the same language used in sanghātiśeșa 17, defining becoming intimate as "mingled in body and speech" (kāyikena samsargena vācikena samsargena). ${ }^{81}$ Nothing about concealing faults is ever mentioned.

78 Both words are from sam- $v s r j$ : to be joined or united or mingled or confused, come into contact with, meet (as friends or foes, also applied to sexual intercourse . . . ). The Kāmasūtra uses samsrsțta at one point specifically with reference to a young girl's intimate relationship with a nun. The nun is suggested to be a good candidate for advancing a naive girl's sexual education (1.3.14). In other places in the Kāmasūtra, it is clearly used to denote sexual intimacy $(1.5 .8,1.5 .8,1.5 .16,2.8 .29)$. In still other places, it merely connotes close association, not necessarily of the sexual kind. This language is one that is used in a range of vinaya contexts to refer to close relationships with inappropriate people (but not necessarily sexual ones); see Horner, The Book of the Discipline, 3:207, note 1. The Kämasūtra uses samsarga for kissing (2.8.6), oral sex (2.9.26), "close contact with loose women" (5.6.45; Doniger and Kakar, Kamasutra, 130), sexual intercourse (6.4.32), and associating with a man (6.5.33).

79 In general, the sanghätiśeșa section of the vinaya is a typical place to find serious, legally important, but not defeating sexual infractions, at least in the case of monks. For instance, rules about masturbation using a hand, using inappropriate suggestive language when talking to women, soliciting pious laywomen for sex and billing it as a form of meritorious offering, and nonsexual physical intimacy, such as touching the hair or hands of a woman, are all found in the sanghātiśeșa section of the bhikșu vinaya. It might be possible to argue, then, that this nun's sanghātiśeșa rule is also put in this section of the vinaya to deal with another legally important sexual infraction.

80 Kālī and her Licchavi maiden also appear in yet another pācattika rule concerning not sending away a disciple who has transgressed the discipline (Hirakawa, Monastic Discipline, 319).

81 Roth, Bhikșunī-vinaya, §200, 225. Hirakawa translates the corresponding Chinese phrase as "to live together so close that they can touch each other mouth to mouth, or that they can touch each other body to body, or that they can touch each other body to body and mouth to mouth" (Hirakawa, Monastic Discipline, 277). The Chinese, however, is the same as in sanghātiśeșa 17 and translates literally as "body habitually close-living, mouth habitually close-living, mouth body habitually close-living." In other words, Hirakawa's translation is deceptive and this passage adds no new information. What really is not clear is who has 
Intriguingly, this pācattika text includes some further commentary, seemingly as an afterthought, specifying that should two nuns stay intimately with one another, spending time delighting in one another, they must be separated. ${ }^{82}$

Rules governing sexual or romantic behaviors for bhikșunis are often found in a different category of offense than the parallel rules for monks. For instance, nonpenetrative physical intimacy between a bhikṣuṇi and a man is a pārājika, but a sañghätiśeșa in the case of a bhikșu and a woman. On the other hand, the Mahāsānighika-lokottaravādin Bhikṣun̄i-vinaya categorizes masturbation by nuns using devices, water, or root vegetables merely as a "transgression of the vinaya" (vinayātikrama), ${ }^{83}$ while masturbation is a sañghātiśeșa for monks, an offense requiring a formal meeting of the order. And, while pārājika-worthy sex is defined as penetrative in nature, the vinaya does not conceive of penetrative sex between two women as counting as a pärājika. In fact, such an act is not specifically mentioned in the Mahāsāñghika-lokottaravādin Bhikșuṇi-vinaya or the Pāli-vinaya as far as I know, though it is mentioned in the Dharmaguptaka-vinaya and, apparently, in

committed a pācattika. It is the Licchavi daughter who is culpable, but in this version of the scenario she is not a bhikșuṇi, only a śramaṇerī. Therefore, the prātimokșa rules cannot apply to her, as she holds only the dasaśila (tenfold discipline or ten novice precepts). Technically, only Kāli is eligible to commit a pācattika, and yet she has not committed the acts that are criticized in this text.

82 Roth, Bhikșunī-vinaya, §200, 225. See also Horner, The Book of the Discipline, 3:248 for a reference to female-female erotic behavior in the Päli-vinaya. Horner's translation of the term of art in this passage (pācattiya 3), talaghātaka, may not be accurate according to Perera, who thinks it refers to two women engaged in "tribadism"; see L. P. N. Perera, Sexuality in Ancient India: A Study Based on the Pali Vinayapitaka (Colombo, Sri Lanka: The Postgraduate Institute of Pali and Buddhist Studies, 1993), 202-203. The Mahāsānghika-lokottaravādin text makes it pretty clear, however, that the term talaghātapratisamyukta means they are putting pressure on the pubic area with the palm of the hand (hastatalenāngajātam prasphotayanti).

83 These rules are found in the prakirnaka section (Roth, Bhikṣuni-vinaya, 306-311; Hirakawa, Monastic Discipline, 392-398). The Chinese translation of the Mahāsānighika-vinaya seems to change the rule about talaghātapratisamyuktam (Roth, Bhikșuñi-vinaya, §265, 306-307) into a story about a single woman, whereas the Mahāsānghika-lokottaravādin rule speaks of nuns masturbating in the plural. The Pāli parallel specifies that two nuns are involved and implies they are mutually "patting" or whatever talaghäta means. Collectively, these rules about masturbation are categorized as pacittiya offenses (offenses requiring confession and expiation) in the Pāli-vinaya and in the Dharmaguptaka-vinaya (Horner, The Book of the Discipline, 3: 248-51; Heirman, Rules for Nuns, 594-601). Vinaya traditions also include rules against nuns being rubbed and massaged by laywomen, nuns, novice nuns, and so forth, except in case of illness (see for instance Hirakawa, Monastic Discipline, 347-351), or rules about nuns sharing a bed or a coverlet (Hirakawa, Monastic Discipline, 347-351; Horner, The Book of the Discipline, 3:304; Perera, Sexuality, 204). 
the Mūlasarvāstivāda-vinaya (though in neither case is it considered a highly serious offense). ${ }^{84}$

In Buddhist vinaya traditions, then, the same-sex passions of women are somewhat dimly, briefly, and vaguely noted as compared to the extensive cataloging of all varieties of male sexuality one finds, for instance, in bhikșu pārājika 1 and the bhikșu sanghātiśeșa rules, and the similar cataloging of women's sexual acts with men or third-sexed individuals in the bhikșuñ pārājika texts. ${ }^{85}$ They are also lightly punished in the vinaya compared to male homosexual or heterosexual sex or, one might say, penetrative sex involving semen. Given the assumed centrality of the Buddhist critique of desire and pleasure in all of its forms, why would this be the case? It may have something to do with what we could characterize, using contemporary terminology, as a marginalization of female queerness in Buddhism combined with a lack of focus on or pure ignorance of modalities of female intimacy by male monastic lawyers. ${ }^{86}$ It may, however, have more to do with the socially, religiously, and economically endorsed forms of heterosexuality that celibacy is defined against in premodern South Asian Buddhism; that is, the iron cage of reproduction and marriage. As Janet Gyatso exhaustively details, the vinaya catalogs sexual acts and places them in hierarchies of transgression, the "gold standard" for which is the quintessentially heterosexual act of a monk's member inserted into the vagina of a woman. ${ }^{87}$ Similarly, José Cabezón observes, "What makes penetrative sex weightiest is the fact that it represents a devolution of the monk to the life of

84 Heirman, Rules for Nuns, 2:597; José Ignacio Cabezón, Sexuality in Classical South Asian Buddhism (Boston: Wisdom Press, 2017), 329, note 840. Here, Heirman back-translates the Chinese term, yin shi ("lewd acts") into Sanskrit as maithuna (which is definitely a reference to the sexual union of a couple; Heirman, Rules for Nuns, 663, note 217). This seems to reverse the standard Sanskrit-Chinese translation practice: maithuna is often rendered as yin shi (see, for instance pārājika 1; Andrew Chittick, personal communication).

85 Derrett also notes, "The Vinaya is not specifically interested in sexual relations between women in nunneries [. . .]”; see J. D. M. Derrett, "Monastic Masturbation in Pāli Buddhist Texts," Journal of the History of Sexuality 15, no. 1 (2006), 1-13. Cabezón notes, "Although the breadth of women's desires and pleasures is acknowledged in the Vinaya, for a nun (a woman), sex is not real sex unless it is with a biological male" (Cabezón, Sexuality, 329).

86 Vatsyāyana's Kāmasūtra mentions women's sexual activities with one another in two places. At 5.6.2-4, women of the harem are described as using dildos, bulbs, roots, fruits, etc. to satisfy each other. The implication of the text is that they are compensating for inadequate male attention, not acting on same-sex sexual preferences. At 7.1.20, the Kāmasūtra mentions girls penetrating one another prior to marriage. See Doniger and Kakar, Kamasutra.

87 Janet Gyatso, "Sex," in Critical Terms for the Study of Buddhism, ed. Donald Lopez (Chicago: University of Chicago Press, 2005), 280. 
the phallus - a life devoted to dominance and conquest in the service of phallic pleasure." 88

It is a basic principle of vinaya hermeneutics that monastic proscriptions exist because situations were happening. In other words, Buddhist monastic women were living together intimately, mingled in body and speech. What the vinaya heavily regulates is two nuns living mingled in body and speech while concealing clearly proscribed faults, not all forms of female-female intimacy per se. Notably, in the Mahāsānghika-lokottara Bhikșuṇi-vinaya, we find a more general statement ruling against two nuns living together intimately and taking sexual pleasure from one another only as a footnote to a pācattika rule. Penetrative sex between two women using a device or nonphallic body part, while usual in same-sex sexuality and arguably meeting the pārājika definition of sex as insertive, is not even mentioned in that context. It is evident that, while female Buddhist monastics are not supposed to be giving each other (or themselves) sexual pleasure, the classical Buddhist legal tradition does not police such behaviors with the utmost rigor. What is of great legal concern, however, is nuns' romantic and sexual behaviors with men, especially monks, and their collusion with one another to "conceal faults." 89

In fact, the central problematic of South Asian Buddhism and other South Asian celibate traditions may not be guarding against desire for emotional and physical intimacy and the pleasure that accompanies it, at least not in the simplistic way we have tended to understand it. ${ }^{90}$ Building on (but departing somewhat from) Gyatso's insights, I would argue that classical Buddhist critiques of sexuality take special aim at certain and specific configurations of reproductively obsessed heteronormative sexuality, something also severely critiqued in the Garbhāvakrānti-sūtra. ${ }^{91}$ Cabezón makes a related point when he notes the

88 Cabezón, Sexuality, 331.

89 Focusing mainly on the Pāli-vinaya, Cabezón makes several of the same observations (Cabezón, Sexuality, 326-333).

90 While she is making a point about the importance of consent or giving into sex in determining culpability, not the point I am making about celibacy creating a space for higher-order desires, Gyatso similarly notes the fact that, in the vinaya, "a desire for sex is not really the problem. The problem is rather the moment of letting or making sex happen" (Gyatso, "Sex," 285).

91 These comments are inspired in part by the work of Madhavi Menon, a queer theorist and literature scholar. In her work of popular scholarship, A History of Desire in India, Menon writes, "Less a giving up of desires than a different organization of one's desire, celibacy suggests a way out of the ritualistic longing for and loathing of sex. Its alternative organization moves us away from a communal monitoring of desire to a more private enjoyment. Getting rid of the rituals for marriage and reproduction laid down by an oppressive community amounts to a radical call for freedom. Celibacy becomes desirable as a way of escaping religious control over one's 
gaps and fissures and loopholes in disciplinary regimes through which people inevitably slip, thereby "constructing alternative sexual lifestyles" that "are the byproducts of the gender-differentiated nature of desire and sexuality." "92 I would argue more positively, however, that, especially for women, Buddhist ascetic discipline is for the purpose of generating a space of purified joy and love, not an emotionally flat space of no pleasure, no love. Read in this light, the sanghātiśeșa 17, with its language of mingling and intimacy, and its concern that women living closely together may be conspiring to conceal faults, is in part about negotiating the gray area between undharmic sexual activity and dharmically acceptable or even beneficial same-sex intimacy and love. The latter is a possibility that emerges within the burned-over, emptied-out spaces of anti-fecundist constructions of womanhood.

These Buddhist texts on affective connections between nuns suggest Buddhist celibacy to be a spiritual practice whose most distinctive marker is not emotional austerity and bodily isolation, as is sometimes assumed, but rather the refusal of the heterosexual and reproductive practices associated with marriage in patriarchal settings, and by extension any insertive sexual acts that involve the emission of semen. In this refusal is born a shadow space of female-female intimacy, ${ }^{93}$ one that appears to have been regarded with suspicion by male monastic lawyers and probably female community leaders also as a potential opportunity for sexual misconduct and female collusion. The vinaya literature clearly recognizes female monastic communities to be social-moral-affective spaces in which, as in the king's harem, expressions of same-sex sexuality may inevitably occur on occasion. These are to be pragmatically disciplined but without extreme rigor. This is in contrast to

desires and asserting independence in the face of repression. Resisting the dominant call to marry and reproduce can be a liberating experience. By definition, then, celibacy is seen as the antisocial choice, the one that flies in the face of what the Brahmans have prescribed. Such an appreciation of celibacy suggests that desire cannot be understood narrowly only as sexual desire; desire is often at its most intense in its renunciation of sex." See Madhavi Menon, A History of Desire in India (Delhi: Speaking Tiger Publishing, 2018), 124. John Powers notes the manner in which the classical tradition lauds Śāiputra and Maudgalyāyana as a monastic couple whose relationship is faithful, long-lasting, and characterized by physical, emotional, and intellectual intimacy. Sāriputra and Maudgalyāyana, for instance, always shared a cell during the long weeks of the rainy-season retreat; see John Powers, A Bull of a Man: Images of Masculinity, Sex, and the Body in Indian Buddhism (Cambridge: Harvard University Press, 2009), 152-160. John Garret Jones argues for what he describes as the homoerotic intimacy of Ānanda's relationship with the Buddha throughout their previous lives together as depicted in the Jātaka collection (noted in Cabeźon, Sexuality, 88-89).

92 Cabezón, Sexuality, 330.

93 As well as male-male intimacy. See Cabezón, Sexuality, 333, note 850. 
penetrative forms of sex involving semen, which are regarded as much more serious offenses. Hence, an adjusted understanding of celibacy as mainly constructed contra-hetero-reproductive forms of sexual intimacy opens up a view of female monastic space as emotionally rich and in which what might be characterized as higher-order passions and purer forms of intimacy can be nurtured and coexist with or even be constitutive of Buddhist monastic life.

\section{Conclusion: Love, Unknowing, and Female Filth}

The Garbhāvakrānti-sūtra and related Buddhist texts about birth suffering rhetorically decimate the goods that were traditionally the purview of women in premodern South Asia: namely, sexualized beauty, cyclical purity, and the auspiciousness that comes with powers of fertility. They do this by transforming the young reproductive mother and her older female helpers (the midwives, aunties, and grandmothers) into heartless purveyors of torture, death, and filth. The victim in this story is the fetus, who is implicitly male and a future Buddhist ascetic. This dramatic Buddhist narrative of birth cedes no higher ground to women. Concealed in the desolate, sharply gendered moral-social landscape of birth suffering, however, is gender-radical potential for women brave enough to enter. Because their conventional value had been denied, I argue, monastic women were free to embrace and explore new notions of the good. They would have found most of these new goods within the formal teachings of the Buddha Dharma. Others, I argue, particularly those associated with their embodied communal lives as women, they would have discovered on their own within the alternative moral-social space of the nunnery. Vinaya literature, with its unusually pragmatic treatment of female blood and interestingly tolerant legislation of female-female affection, affords an intimate glimpse of what that new space of being and becoming might have felt like and been like for premodern monastic women living in community. Following the thread from the Garbhāvakrānti-sūtra to prakīṇaka 15 and sañghātiśeșa 17 illuminates an alternative world of embodied female living in which menstrual blood is merely a practical problem, not a fragment of sakti or a cosmic disaster, and love is possible beyond the strictures of the reproductive, the heteronormative, and the patriarchal. 


\section{Bibliography}

Anālayo. “Anguttara-nikāya/Ekottarika-Āgama: Outstanding Bhikkhunīs in the Ekottarika-Āgama.” In Women in Early Indian Buddhism: Comparative Textual Studies, edited by Alice Collett, 97-115. New York: Oxford University Press, 2014.

Anālayo. "Saṃyutta-nikāya/Samyukta-Āgama: Defying Māra-Bhikkunīs in the SamyuktaĀgama." In Women in Early Indian Buddhism: Comparative Textual Studies, edited by Alice Collett, 116-39. New York: Oxford University Press, 2014.

Barnes, Nancy J. "Nuns at the Stūpa." In Women's Buddhism, Buddhism's Women, edited by Ellison Banks Findly, 17-36. Somerville, MA: Wisdom, 2000.

Bautze-Picron, Claudine. "The Lady under the Tree - A Visual Pattern from Māyā to the Tãrā and Avalokiteśvara." In The Birth of the Buddha, edited by Cristoph Cueppers, Max Deeg, and Hubert Durt, 193-237. Lumbini: Lumbini International Research Institute, 2010.

Beal, Samuel, ed. Si-Yu-Ki, Buddhist Records of the Western World. Calcutta: Susil Gupta, 1958.

Bka' 'gyur (sde dge par phud). 103 vols. Delhi: Delhi Karmapae Chodhey Gyalwae Sungrab Partun Khang, 1976-1979. TBRC W22084. Accessed July 22, 2019. http://tbrc.org/link? RID.W22084.

Bka' 'gyur (stog pho brang bris ma), 109 vols. Leh: Smanrtsis Shesrig Dpemzod, 1975-1980. TBRC W22083. Accessed July 22, 2019. http://tbrc.org/link?RID.W22083.

Blackstone, Kathryn R. Women in the Footsteps of the Buddha: Struggle for Liberation in the Therigatha. Surrey: Curzon Press, 1998.

Bodhi, Bhikkhu, ed. The Connected Discourses of the Buddha: A New Translation of the Samyutta Nikāya. Boston: Wisdom Publications, 2000.

Bodhi, Bhikkhu, ed. The Numerical Discourses of the Buddha: A Translation of the Ariguttara Nikāya. Boston: Wisdom Publications, 2012.

Bodhi, Bhikkhu and Bhikkhu Ñannamoli, eds. The Middle Length Discourses of the Buddha: A Translation of the Majjhima Nikāya. Boston: Wisdom Publications, 2005.

Cabezón, José Ignacio. "Homosexuality and Buddhism." In Homosexuality and World Religions, edited by A. Swidler, 81-101. Valley Forge, PA: Trinity Press International, 1993.

Cabezón, José Ignacio. Sexuality in Classical South Asian Buddhism. Somerville, MA: Wisdom Publications, 2017.

Choo, Jessey. “That 'Fatty Lump': Discourses on the Fetus, Fetal Development, and Filial Piety in China Before the Eleventh Century CE." Nan Nü 14 (2012): 177-221.

Clarke, Shayne Neil. Family Matters in Indian Buddhist Monasticisms. Honolulu: University of Hawai'i Press, 2014.

Cohen, Richard. "Nāga, Yakșiṇi, Buddha: Local Deities and Local Buddhism at Ajanta." History of Religions 37, no. 4 (1998): 360-400.

Collett, Alice. "Therīgāthā: Nandā, Female Sibling of Gotama Buddha." In Women in Early Indian Buddhism: Comparative Textual Studies, edited by Alice Collett, 140-59. New York: Oxford University Press, 2014.

Collett, Alice. "Women as Teachers and Disciples in Early Buddhist Communities: The Evidence of Epigraphy." Religions of South Asia 9, no. 1 (2015): 28-42.

Collett, Alice. "Reimagining the Sātavāhana Queen Nāgaṇnikā.” Journal of the International Association of Buddhist Studies 41 (2018): 329-358. 
Couture, André. 2009. “The Story of Saṃkarșaṇa’s and Kṛṣna’s Births: A Drama Involving Embryos." In Imagining the Fetus: The Unborn in Myth, Religion, and Culture, edited by Vanessa Sasson and Jane Marie Law, 11-31. New York: Oxford University Press, 2009.

Das, Rahul. The Origin of the Life of a Human Being: Conception and the Female according to Ancient Indian Medical and Sexological Literature. 1st ed. Delhi: Motilal Banarsidass Publishers, 2003.

DeClercq, Eva. “The Great Men of Jainism in Utero: A Survey." In Imagining the Fetus: The Unborn in Myth, Religion, and Culture, edited by Vanessa Sasson and Jane Marie Law, 33-54. New York: Oxford University Press, 2009.

Dehejia, Vidya, and Thomas B Coburn. Devi: The Great Goddess: Female Divinity in South Asian Art. Washington, DC: Published by the Arthur M. Sackler Gallery, Smithsonian Institution in association with Mapin Publishing, Ahmedabad and Prestel Verlag, Munich, 1999.

Derrett, J. D. M. “Monastic Masturbation in Pāli Buddhist Texts." Journal of the History of Sexuality 15, no. 1 (2006): 1-13.

Doniger, Wendy, ed. Norton Anthology of World Religions: Hinduism. New York: W. W. Norton \& Company, 2015.

Doniger, Wendy, and Sudhir Kakar, eds. Kamasutra. New York: Oxford University Press, 2002.

Finnegan, Damchö Diana. “For the Sake of Women, Too": Ethics and Gender in the Narratives of the Mūlasarvāstivāda Vinaya. PhD diss., University of Wisconsin-Madison, 2009.

Garrett, Frances. “Ordering Human Growth in Tibetan Medical and Religious Embryologies.” In Textual Healing: Essays on Medieval and Early Modern Medicine, edited by Elizabeth Lane Furdell, 31-52. Leiden: Brill, 2005.

Garrett, Frances. Religion, Medicine and the Human Embryo in Tibet. Abingdon-on-Thames: Routledge, 2008.

Gnoli, Raniero, and T. Venkatacharya. The Gilgit Manuscript of the Sanghabhedavastu: Being the 17th and Last Section of the Vinaya of the Mülasarvāstivādin. Vol. 1. Roma: Istituto Italiano per il Medio ed Estremo Oriente, 1977.

Goodman, Charles, ed. The Training Anthology of Śāntideva: A Translation of the Śikșāsamuccaya. New York: Oxford University Press, 2006.

Göttingen Register of Electronic Texts in Indian Languages (GRETIL). "Vatsyayana, Kamasutram.” Accessed July 29, 2019. http://gretil.sub.uni-goettingen.de/gretil/1_sanskr/6_sastra/ 6_kama/kamasutu.htm.

Göttingen Register of Electronic Texts in Indian Languages (GRETIL "Vinayasutra. Preliminary transliteration of the ms. found in Tibet by Rahula Sankrityayana." Accessed July 29, 2019. www.sub.uni goettingen.de/ebene_1/fiindolo/gretil/1_sanskr/4_rellit/buddh/ vinsutrc.txt.

Gyatso, Janet. "Sex." In Critical Terms for the Study of Buddhism, edited by Donald Lopez, 271-290. Chicago: University of Chicago Press, 2005.

Granoff, Phyllis. "My Rituals and My Gods: Ritual Exclusiveness in Medieval India." Journal of Indian Philosophy 29, no. 1 (2001): 109-34.

Heirman, Ann. Rules for Nuns according to the Dharmaguptakavinaya. Delhi: Motilal Banarsidass Publishers, 2002.

Hirakawa, Akira. Monastic Discipline for the Buddhist Nuns: An English Translation of the Chinese Text of the Mahāsāmghika-Bhikșuṇi-Vinaya. Patna: Kashi Prasad Jayaswal Research Institute, 1982. 
Horner, I. B., ed. The Book of the Discipline (Vinaya-pitaka). Vols 1-6. Bristol: The Pali Text Society, [1938-1966] 2012-2014.

Hüsken, Ute. “Pure or Clean?” Traditional South Asian Medicine 6 (2001): 85-96.

Jyväsjärvi, Mari Johanna. Fragile Virtue: Women's Monastic Practice in Early Medieval India. PhD diss., Harvard University, 2011.

Kapani, Lakshmi. Garbhopaniṣad. Paris: A. Maisonneuve, 1976.

Kim, Jinah. "Unheard Voices: Women's Roles in Medieval Buddhist Artistic Production and Religious Practices in South Asia." Journal of the American Academy of Religion 80, no. 1 (2012): 200-232.

Kosambi, D. D. Ancient India: A History of Its Culture and Civilization. New York: Pantheon Books, 1966.

Kritzer, Robert. "Life in the Womb: Conception and Gestation in Buddhist Scripture and Classical Indian Medical Literature." In Imagining the Fetus: The Unborn in Myth, Religion, and Culture, edited by Vanessa Sasson and Jane Marie Law, 73-90. New York: Oxford University Press, 2009.

Kritzer, Robert. "Tibetan Texts of Garbhāvakrāntisūtra: Differences and Borrowings.” Annual

Report of the International Research Institute for Advanced Buddhology 15 (2012): 131-45.

Kritzer, Robert. "Garbhāvakrāntau ('In the Garbhāvakrānti'): Quotations from the Garbhāvakrāntisūtra in Abhidharma Literature and the Yogācārabhūmi." In The Yogācārabhūmi and the Yogācāras, edited by Ulrich Timme Kragh, 738-71. Cambridge: Harvard University, Department of Sanskrit and Indian Studies, 2013.

Kritzer, Robert. Garbhāvakrāntisūtra: The Sūtra on Entry into the Womb. Studia Philologica

Buddhica 31. Tokyo: The International Institute for Buddhist Studies, 2014.

Kritzer, Robert. "'Women Who Know about That': Midwives and Wise Women in Buddhist Literature." Unpublished manuscript. Accessed July 29, 2019. https://www.academia. edu/38300468/For_Academia_revised_4.7_Submission_Women_who_Know_about_ That_-_Midwives_and_Wise_Women_in_Buddhist_Literature.docx.

Lang, Karen Christina. Four Illusions: Candrakirti's Advice for Travelers on the Bodhisattva Path. New York: Oxford University Press, 2003.

Langenberg, Amy Paris. "Pregnant Words: South Asian Buddhist Tales of Fertility and Child Protection." History of Religions 52, no. 4 (2013): 340-369.

Langenberg, Amy Paris. "Mahāsānighika-Lokottaravāda Bhikșuṇi Vinaya: The Intersection of Womanly Virtue and Buddhist Asceticism." In Women in Early Indian Buddhism: Comparative Textual Studies, edited by Alice Collett, 80-96. Oxford: Oxford University Press, 2014.

Langenberg, Amy Paris. "Kșemendra's Garbhāvakrāntyavadāna through a Tibetan 'LookingGlass." In In Vimalakirti's House: A Festschrift in Honor of Robert A. F. Thurman on the Occasion of His 70th Birthday, edited by Christian Wedemeyer, John D. Dunne, and Thomas Yarnall, 119-130. Treasury of the Buddhist Sciences (AIBS). New York: Columbia University Press, 2015.

Langenberg, Amy Paris. "Buddhist Blood Taboo: Mary Douglas, Female Impurity, and Classical Indian Buddhism." Journal of the American Academy of Religion 84, no. 1 (2016): 157-191. Langenberg, Amy Paris. Birth in Buddhism: The Suffering Fetus and Female Freedom. Critical Studies in Buddhism. Abingdon-on-Thames: Routledge Press, 2017. Langenberg, Amy Paris. "Fetal Suffering in the Descent of the Embryo Sūtra." In Buddhism and Medicine: A Sourcebook, edited by C. Pierce Salguero, 41-47. New York: Columbia University Press, 2017. 
Langenberg, Amy Paris. "An Imperfect Alliance: Feminism and Contemporary Female Buddhist Monasticisms.” Religions 9, no. 190 (2018): 1-24.

Langenberg, Amy Paris. "On Reading Vinaya: Feminist History, Hermeneutics, and Translating the Female Body." In Translating Buddhism: Historical and Contextual Perspectives, edited by Alice Collett. New York: SUNY Press, forthcoming.

Mahāsañgīti Tipițaka Buddhavasse. World Tipițaka Edition in Roman Script. Edited and published by The M. L. Maniratana Bunnag Dhamma Society Fund, 1957. Accessed July 29, 2019. https://suttacentral.net.

Menon, Madhavi. A History of Desire in India. Delhi: Speaking Tiger Publishing, 2018.

Milligan, Matthew D. "The Economic Power of Women in Early South Asian Buddhism." The Indian Economic and Social History Review 56, no. 1 (2019): 1-25.

Muldoon-Hules, Karen. “Avadānaśataka: The Role of Brahmanical Marriage in a Buddhist Text." In Women in Early Indian Buddhism: Comparative Textual Studies, edited by Alice Collett, 192-220. New York: Oxford University Press, 2014.

Nolot, Édith. Règles de Discipline des Nonnes Bouddhistes. Collège de France, Publications de l'institute de Civilisation Indienne, Fascicule 60. Paris: Diffusion de Boccard, 1991.

Oldenberg, H., ed. Vinaya-pițaka. Oxford: Pali Text Society, 1879-1883.

Olivelle, Patrick, ed. Dharmasūtras: The Law Codes of Apastamba, Gautama, Baudhāyana, and Vasiștha. Delhi: Motilal Banarsidass, 2003.

Olivelle, Patrick, ed. Manu's Code of Law: A Critical Edition and Translation of the MānavaDharmaśāstra. Oxford: Oxford University Press, 2005.

Perera, L. P. N. Sexuality in Ancient India: A Study Based on the Pali Vinayapitaka. Colombo, Sri Lanka: The Postgraduate Institute of Pali and Buddhist Studies, 1993.

Powers, John. A Bull of a Man: Images of Masculinity, Sex, and the Body in Indian Buddhism. Cambridge: Harvard University Press, 2009.

Pradhana, Prahlada, ed. Abhidharmakośa-Bhāṣyam. Patna: K. P. Jayaswal Research Institute, 1967.

Quagliotti, Anna Maria. “An Inscribed Image of Hārītī in the Chandigarh Government Museum and Art Gallery." Silk Road Art and Archaeology 6 (1999): 51-60.

Roth, Gustav, ed. "The Woman and Tree Motif: Śālabhañjikā-Ḍālamālikā in Prakrit and Sanskrit Texts with Special Reference to Śilpaśāstras Including Notes on Dohada." Journal of the Asiatic Society 23, no. 1 (1957): 91-44.

Roth, Gustav, ed. Bhikșuṇi-Vinaya Including Bhikșuṇi-Prakīrṇaka and a Summary of the Bhikșu-Prakīrnaka of the Ārya-Mahāsāṃghika-lokottaravādin. Patna: K. P. Jayaswal Research Institute, 1970.

Roy, Kumkum. "Women and Men Donors at Sanchi: A Study of Inscriptional Evidence." In Position and Status of Women in Ancient India, no. 1 (1988): 209-23.

Schopen, Gregory. "On Monks, Nuns, and 'Vulgar' Practices: The Introduction of the Image Cult into Indian Buddhism." In Bones, Stones, and Buddhist Monks: Collected Papers on the Archaeology, Epigraphy, and Texts of Monastic Buddhism in India, 238-57. Honolulu: University of Hawai'i Press, 1997.

Schopen, Gregory. "The Suppression of Nuns and Ritual Murder of Their Special Dead." In Buddhist Monks and Business Matters: Still More Papers on Monastic Buddhism in India, 329-59. Honolulu: University of Hawai'i Press, 2004.

Schopen, Gregory. "The Urban Buddhist Nun and a Protective Rite for Children in Early North India." In Pāsādikadānam: Festschrift für Bhikkhu Pasadika, edited by M. Straube, 359-380. Marburg: Indica et Tibetica Verlag, 2009. 
Selby, Martha. 2005. "Narratives of Conception, Gestation, and Labour in Sanskrit Āyurvedic Texts." Asian Medicine 1, no. 2 (2005): 254-75.

Smith, Frederick. "Narrativity and Empiricism in Classical Indian Accounts of Birth and Death: The Mahābhārata and the Saṃhitās of Caraka and Suśruta." Asian Medicine 3, no. 1 (2007): 85-102.

Trikamji Ācārya, and Vaidya Jādavaji, eds. The Carakasaṃitā of Agniveśa. New Delhi: Munshiram Manoharlal, 1981.

Vaidya, Paraśurāma, ed. Lalita-Vistara. Darbhanga: Mithila Institute of Post-Graduate Studies and Research in Sanskrit Learning, 1958.

Van Schaik, Sam. "A Tibetan Book of Spells." Early Tibet: Notes, Thoughts, and Fragments of Research on the History of Tibet (blog), February 19, 2009. Accessed July 29, 2019. https://earlytibet.com/2009/02/19/a-tibetan-book-of-spells/.

Van Schaik, Sam. "A Tibetan Book of Spells." Unpublished manuscript, last accessed September 4, 2018, pdf file.

Walshe, Maurice. Thus Have I Heard: The Long Discourses of the Buddha. London: Wisdom Publications, 1987.

Wijesekera, O. H. "Vedic Gandharva and Pāli Gandhabba." University of Ceylon Review 3, no. 1 (1945): 73-107.

Yamabe, Nobuyoshi. "Parallel Passages between the Manobhūmi and the Yogācārabhūmi of Samgharakșa." In The Foundation for Yoga Practitioners: The Buddhist Yogācārabhūmi Treatise and Its Adaptation in India, East Asia, and Tibet, edited by Ulrich Timme Kragh, 596-737. Harvard Oriental Series 75. Cambridge: Harvard University Press, 2013. 